\title{
THE SOCIAL EXCLUSION OF PERSONS WITH DISABILITIES FROM TERTIARY EDUCATION - TARGETING BARRIERS DEPENDING ON THE TYPE OF DISABILITY BASED ON THE FINDINGS OF A QUALITATIVE STUDY
}

\author{
UDC 378.1-056.26
}

\author{
Aleksandra Nikolajević \\ University of Niš, Faculty of Philosophy, Department of Sociology, Serbia
}

\begin{abstract}
In this paper, we primarily dealt with the low representation of persons with disabilities in the tertiary education system and targeted specific barriers that keep people with disabilities outside the tertiary education process. The mentioned problem was approached from the perspective of social exclusion and one of the main tasks of the conducted research was to gain insight into the types of barriers that affect persons with different types of disabilities depending on their student status (they did not enroll at a university, they discontinued their studies, they are currently studying, they have completed their studies). The results were gained by conducting in-depth interviews covering all the mentioned categories of persons with disabilities. The results of the research point to the existence of numerous obstacles that people with disabilities face in the process of acquiring tertiary education. It has turned out that the surveyed persons with disabilities face insurmountable obstacles in the form of architectural, institutional and social barriers, depending on the type of disability and their social environment.
\end{abstract}

Key words: social exclusion, education, people with disabilities, barriers.

\section{INTRODUCTION}

It is indisputable that every society faces an unequal distribution of social resources, which, to a greater or lesser extent, leads to social inequalities, and unequal possibilities and opportunities for all citizens to progress with no hindrances and occupy desirable social positions. It is a general tendency for all the members of a society be equal in their ability to realize their potential and achieve desirable social goals, even though the social reality often witnesses certain social groups being excluded from some social processes

Received April 5, 2017 / Accepted April 27, 2019

Corresponding author: Aleksandra Nikolajević

University of Niš, Faculty of Philosophy, Ćirila i Metodija 2, 18000 Niš, Serbia

E-mail: aleksandra.nikolajevic@filfak.ni.ac.rs 
and flows. In order to understand the concept of social exclusion (and apply this concept to a group of people with disabilities in the sphere of tertiary education), we also need to explain the notion of social inclusion, since the concept of social exclusion is measurable exclusively in relation to social inclusion.

\section{THE CONCEPT OF SOCIAL EXCLUSION/INCLUSION, THE THEORETICAL FRAMEWORK AND PREVIOUS RESEARCH}

The EU Council has outlined its official definition of the concept of social inclusion. In summary, the definition points to the ability of all members of society to participate equally in various spheres of social life and achieve an adequate standard of living and well-being. "It ensures that they have greater participation in decision making which affects their lives and access to their fundamental rights" (EU Council 2004, 8). In the same document, social exclusion is defined as:

\footnotetext{
"a process whereby certain individuals are pushed to the edge of society and prevented from participating fully by virtue of their poverty, or lack of basic competencies and lifelong learning opportunities, or as a result of discrimination. This distances them from job, income and education opportunities as well as social and community networks and activities. They have little access to power and decision-making bodies and thus often feeling powerless and unable to take control over the decisions that affect their day to day lives." (EU Council 2004, 8).
}

The cited definitions lead us to the conclusion that social exclusion is multidimensional and that some individuals may encounter social exclusion in several related social systems. In this way, the links between the individual and society are weakened, which is why they are excluded from the community.

In addition to the many attempts at defining and operationalizing the notion of social exclusion in scientific circles (Silver, 1994; Sen, 2000; Rawal, 2008; Dejong, 1979), there are also attempts to prevent the exclusion of certain social groups ${ }^{1}$ through legislation and international legal acts ${ }^{2}$. The institutional aspects of social exclusion are recognized in The Constitution of the Republic of Serbia ("Official Gazette of the Republic of Serbia" No. 98/2006), The Law on the Prohibition of Discrimination ("Official Gazette of the Republic of Serbia, No. 22/2009), and the Law on the Prohibition of Discrimination of Persons with Disabilities ("Official Gazette of the Republic of Serbia" No. 98/2006). Article 18 of the latter law unambiguously states the prohibition of discriminating against persons with disabilities (PwDs) in all levels of education and upbringing, i.e., denying PwDs education due to their disability. It is also necessary to mention Article 13 of the same Law, which prohibits discrimination based on disability in relation to the availability of services and access to publicly used facilities and public spaces. Referring to international legal acts that guarantee rights to this vulnerable group, we will mention not only the Universal Declaration of Human Rights but also the special conventions adopted with the aim of ensuring the realization of the rights of persons with disabilities. The ratification of the Convention on the Rights of Persons with Disabilities is of great importance for the

\footnotetext{
${ }^{1}$ In the remaining part of the paper, special emphasis is placed on persons with disabilities (hereinafter: PwDs). ${ }^{2}$ The following part of the paper gives an overview of the laws predominantly focused on the position and rights of persons with disabilities.
} 
Republic of Serbia because the full implementation of the said Convention would significantly improve the life and position of PwDs. Having this in mind, the violation of the right to education, as one of the fundamental human rights, constitutes an act of discrimination and is categorized as social exclusion.

All the aforementioned ideas defined by international legal acts and the laws of the Republic of Serbia coincide with the notion of social exclusion. The broad character of the concept of social exclusion gives us the opportunity of focusing on various forms of exclusion and provides insight into the spheres from which individuals and social groups are excluded. The concept of social exclusion is multidimensional, i.e., individuals may face one or more forms of social exclusion. The wide character of the term points to different areas in which deprivation can occur - economic (unemployment, deprivation of income), political (possibility to exercise their rights and decide on their own life), social and cultural (education, personal contacts, access to cultural resources), etc. (Gidens, 2007). The sphere of social exclusion to which we pay special attention is tertiary education.

Tertiary education is a "mechanism" through which social inclusion is accomplished, i.e., one of the important factors for reducing social exclusion. Tertiary education has several aspects of significance for an individual. On the one hand, it is an important channel of vertical mobility that enables a person to take their place in the hierarchy of social positions. Highly educated individuals acquire competencies and skills (for a series of occupations with more complex content) and become competitive on the labor market. ${ }^{3}$ On the other hand, tertiary education also provides non-material benefits. Tertiary education is characterized by developing the potential to understand the social events and relationships that directly or indirectly surround us and that concern our daily existence. In addition to having a direct impact on critical thinking and perceiving reality, it has a strong effect on the access to a larger amount of social resources and social and cultural capital. Apart from that, the psychological aspect of exclusion from the education system should not be neglected, as it leaves great consequences not only on personal development, selfperception, and the possibility of self-actualization but also on the way others see and experience us. A lack of education prevents one from taking on a whole range of social roles and reduces the chances of the expected social roles being successfully performed. The aforementioned expectations and the achievement of social roles are acquired not only through secondary socialization (interpersonal communication with peers), but also through going through as many educational levels as possible (Rot 2003, 263).

Opportunities for PwDs to get an education and access tertiary education like most of the population without disabilities are significant for their self-actualization and the position of PwDs in society. Some studies have shown that the position of PwDs regarding many aspects of life is significantly worse than the rest of the population. Concerning the topic we are dealing with, it is important to mention the study that indicates that the insufficient inclusion of PwDs reproduces the stigmatization and labeling of this category of the population (Petrović 2012). If the previous practice of excluding PwDs from the education system was addressed, the prevalent unfavorable evaluation of this social group would decrease. We emphasize that this research points to the existence of stigma, social distance, and discrimination of PwDs in the education system. Another significant research provides a detailed description of the satisfaction of PwDs with available social

\footnotetext{
${ }^{3}$ The possibility of choosing a business position, working conditions and various benefits, the amount of monetary benefits, the possibility of further promotion and improvement, etc.
} 
(formal and informal) support, considering the position of PwDs depending on their socio-demographic characteristics (Blažeka Kokorić et al. 2012). The results obtained indicate a much higher level of satisfaction with informal sources of support (family and friends) than formal ones.

The fact that the participation of PwDs in tertiary education is smaller than their representation in the total population. ${ }^{4}$ It is conceptualized through the notion of social exclusion because this term coincides with the social model of approach to disability. Starting from the social model of approach to disability, we are guided by the idea that all members of society should participate freely in all spheres of social life while the responsibility for a potential impossibility of participation is transferred to the society and not individuals. ${ }^{5}$

\section{The SubJeCt Matter, Methodology, and MANner of Data Analysis}

The subject of this paper are the obstacles that hold persons with disabilities outside of the tertiary education system, i.e., they result in their poor enrollment into tertiary education institutions and their frequent abandonment. The main objectives of this study are to describe the exclusion of PwDs from tertiary education, as well as to determine the reasons for their exclusion (physical, institutional, social, or other barriers). The basic goal is to understand the types of barriers which affect people with different types of disabilities in different phases of their (non-)studying (they did not enroll at a university, they discontinued their studies, their studies are under way, and they have graduated from a university). The method used in this research is a multiple case study, while the technique of an in-depth interview established which barriers keep PwDs out of the tertiary education system, depending on the type of disability. In-depth interviews with 13 PwDs were conducted for the needs of our research. ${ }^{6}$ Coverage of the interviewed population includes all types of sensory and motor disabilities ${ }^{7}$ and different student statuses (they did not enroll at a university, but they wanted to, they were enrolled but they discontinued their studies, their studies are under way, and they have graduated from a university). Selecting respondents in this way enables gaining insight into the entirety of the problems that affect PwDs throughout the whole study process. In-depth interviews gave us insights not only into PwD problems during the course of their studies but also into the barriers ${ }^{8}$ that represent an insurmountable obstacle towards becoming a part of tertiary education to a certain type of PwDs.

The in-depth interview was guided and directed towards a pre-constructed instrument composed of four parts. The first part presents the general socio-demographic characteristics

\footnotetext{
${ }^{4}$ The As-is State Report (ASR 2012) gives a picture of unequal tertiary education coverage of various categories of the population of Serbia. The study pointed to the problem of poor representation of PwDs in tertiary education, i.e., to a significantly lower number of students with disabilities in tertiary education as compared to their participation in the entire population.

${ }^{5}$ For a detailed discussion on the model of approaching disability see: Petrović 2007.

${ }^{6}$ Out of the total number of respondents, 10 participants enrolled at a university while 3 of the respondents failed. Within the first group of respondents who enrolled at a university, 4 people are currently in the process of studying, 1 has discontinued their studies, and 4 have completed them.

${ }^{7}$ Two types of persons with disabilities are targeted: 1) those within the education process, 2) those outside of the tertiary education system.

${ }^{8}$ The research started from the already confirmed assumptions that PwDs encounter architectural, institutional, and social barriers, which are findings from various research papers on this topic (see the research of Dinkić et al. 2008; Blažeka Kokorić et al. 2012, Mirić 2014).
} 
of the respondents. The second part of the instrument refers to the architectural barriers that block access to faculties and educational institutions. The third part establishes the extent to which the institutions have provided conditions for the smooth participation of PwDs in the higher education system. Finally, the fourth part establishes a measure of the way the presence of social distance towards PwDs, as well as the (non-)existence of primary and secondary support, ${ }^{9}$ affect the motivation for education.

The analysis of the obtained results was carried out along four dimensions: type of disability, student status, types of barriers, and the way of overcoming the barriers. Along the first dimension of the analysis, we have 6 categories within the motor and sensory type of disability: a milder version of motor disability, a more serious type of motor disability (inborn); a more serious type of motor disability (acquired); sensory disability - vision (inborn); sensory disability - vision (acquired); sensory disability - hearing. Along the second dimension, the analysis of the "student status", we considered four categories: those who wanted to enroll at a university but did not, those who enrolled and discontinued their studies, those who are in the process of studying, and those who completed their studies. The third dimension, the analysis of the "barrier types", indicates barriers of an architectural, institutional, social $^{10}$, and cognitive-motivational ${ }^{11}$ nature which affect PwDs to a varying extent. The fourth dimension concerns support, i.e., the way of overcoming the barriers.

The subsequent part of the paper will show barriers common to all persons with the same type of disability, as well as specific barriers faced by persons with the same type of disability depending on their student status.

\section{RESEARCH RESULTS AND DISCUSSION}

\subsection{Barriers faced by respondents who did not enroll at their desired faculties or have discontinued their studies (architectural, institutional, social, and cognitive-motivational barriers ${ }^{12}$ )}

\subsubsection{Common barriers regardless of the type and time of acquiring the disability}

All interviewed persons with disabilities who did not enroll at a university had a problem overcoming some of the barriers of an architectural and institutional nature. Within the investigated group, those who did not enroll at a university but wanted to or enrolled and discontinued their studies mainly listed architectural and institutional barriers as the reasons for doing so.

\footnotetext{
${ }^{9}$ What is meant is the support of the family and the peer group.

${ }^{10}$ For the purposes of the research, the three dominant types of barriers are operationalized in the following way: physical barriers are recognized as the absence of assistive technology (lifts, restrooms, adapted benches, ramps, handrails, tactile tape, sensory guidance, custom entrances to the library, etc.). Therefore, the nonexistence of systemic support to overcome this obstacle is also a part of the physical barriers. Indicators of institutional barriers are the unadapted process of taking the entrance examination, the inaccessibility of information, unadapted literature, unadapted classes, unadapted assessment, unadapted examination taking, the lack of learning assistance services, and the lack of institutional assistance (student loan or scholarship). The indicators of social barriers in the education process are recognized in the psycho-social barriers - the distanced and discriminatory behavior of a group of peers and teachers (professors) towards PwDs.

${ }^{11}$ The latter is defined and elaborated as a result of the analysis of the obtained results / statements and it represents a substantial scientific contribution of this research.

${ }^{12}$ The cognitive-motivational barrier - a specific barrier characteristic for people with hearing sensory disabilities and attending special schools.
} 


\subsubsection{Architectural barriers}

The biggest problems for those who did not enroll at a university but wanted to (or enrolled but discontinued their studies) regardless of the type of disability are the problems of physical inaccessibility. The practice is that personal assistance is granted to people with a severe disability, so people with a milder form of disability are forced to rely on primary sources of support - parents and friends. The research showed that even with the support of primary groups, people with disabilities did not enroll at a university because they failed to overcome the following physical barriers: lack of handrails, lack of adequate ramps, inaccessible space for taking the entrance exam, inaccessible toilets (M. I.). In this context, it makes sense to say that choosing an accessible faculty ${ }^{13}$ is one of the ways of overcoming architectural barriers.

Persons with severe motor disabilities who have not enrolled at their desired faculty or have terminated their studies state the physical inaccessibility of the faculty as an important barrier. The issue is the inability to overcome the following obstacles: inaccessible streets, transport that is not adapted, and poor accessibility of the faculty. The dominant way of overcoming the physical inaccessibility of the environment and the faculty is the primary source of support (parents and friends) that compensates for the lack of personal assistance. It is important to note that people who do not study have not managed to overcome the mentioned architectural barriers (A. A. and I. N.).

\subsubsection{Institutional barriers}

The lack and inaccessibility of information is the barrier that affects all persons with disabilities outside the education system and those who discontinued their studies. PwDs that had information on the enrollment, the way of taking the entrance exam, the quotas, and other important issues are currently in the process of studying. On the other hand, people with disabilities who lack information ${ }^{14}$ are not in the process of studying despite their efforts to reach the necessary information in various ways.

\subsubsection{Specific barriers in relation to the type of disability and the time it was acquired}

Persons with disabilities who have not enrolled at their desired faculty or have discontinued their studies encounter certain institutional barriers inherent to their type of disability. A significant fact is that each of the detected barriers directly correlates with the specific type of disability of the persons interviewed.

\subsubsection{The cognitive-motivational barrier}

Cognitive-motivational barriers exclusively affect persons with hearing impairments attending special secondary schools for children with hearing impairment. The fact that attending a special secondary school for children with hearing impairment is in conjunction with the cognitive-motivational barrier is illustrated by the following findings: while a person in the study process (M. O. ${ }^{15}$ has no problems with cognitive-motivational barriers (primarily because of attending regular secondary school) ${ }^{16}$, a person who attended a

\footnotetext{
${ }^{13}$ In terms of physical and institutional adaptedness.

${ }^{14}$ Attempts of PwDs to find out the necessary information are possible through primary sources of support (Student's Office at the faculty) and secondary e-resources (website of the faculty).

${ }^{15}$ It is a person with a sensory disability - a complete hearing impairment.

${ }^{16}$ This enabled the development of cognitive-motivational dispositions necessary for tertiary education.
} 
secondary school for children with hearing impairment ${ }^{17}$ (M. S.) faces the problem of underdeveloped cognitive dispositions for abstract thinking. The content of the curriculum at the level of secondary-school special education for children with hearing impairments almost systematically abolishes the possibility for the further education of persons with hearing impairment. It is precisely this institutional barrier that is the cause of poor motivation for tertiary education and the poor participation of people with complete hearing impairment in the studying process. A significantly impoverished program reduced to solving practical tasks (communication) is not an adequate starting point for people with sensory (hearing) disabilities to adopt the necessary knowledge and develop dispositions for abstract thinking that qualify them to continue their education.

4.1.2.2. Ignorance of effective strategies for learning and mastering the study material (institutional barrier)

One of the main reasons for a person (I. N.) with a more severe type of motor disability to terminate their studies is the lack of knowledge of effective strategies for mastering the learning material that should have been adopted back in secondary school. The lack of a service that would help with learning in secondary schools and faculties can be a decisive factor for discontinuing the studies and the lack of motivation. The institutional solution is reflected in the existence of a Students' Office or some other form of student support organization, which would help freshmen overcome problems related to the skill of effective and functional learning.

\subsubsection{Absence of primary support}

The lack of primary support (family and peer group) in overcoming architectural and institutional barriers is an insurmountable obstacle for some respondents. While most respondents in the process of studying state primary support as a key factor for a positive outcome in their tertiary education process,${ }^{18}$ we see that in the case where it is absent, it affects the lack of success in the education process (I. N.).

\subsubsection{Peer discrimination (social barrier)}

There is a diversity of experience in peer discrimination. The research has shown that social barriers vary in their degree of affecting people with disabilities. Discrimination and stereotypes by the professors at the desired faculty is a type of social barrier indicated by the respondent (M. I.), ${ }^{19}$ who did not enroll at their desired faculty, despite having the desire to do so. While the experiences of the interviewed persons in the education process are positive regarding the professors, a person who did not enroll at their desired faculty had a particularly negative experience, which was reflected in their confidence and created a fear of (non-)acceptance. ${ }^{20}$

\footnotetext{
${ }^{17}$ Research shows that in special secondary schools, the impoverished content of the educational curriculum is a key problem for the further education of people with this type of disability.

${ }^{18}$ Either they are still in the process of education or they have successfully completed their studies.

${ }^{19}$ It is about PwDs with severe motor disabilities.

${ }^{20}$ It is important to note that while many PwDs are encountering social barriers, research shows that the persons with disabilities acquired during the course of their study overcome them more easily (because of the already established circle of close people and friends).
} 
In summary, in order to overcome social barriers, two findings are important: 1) for most respondents, primary support is an important factor in overcoming this barrier, ${ }^{21}$ 2) people with sensory disabilities are more likely to overcome these barriers (but, on the contrary, they face insurmountable cognitive-motivational barriers and those of an institutional nature). ${ }^{22}$

\subsection{Barriers faced by respondents who have enrolled at or graduated from their desired faculties (architectural, institutional, social, and cognitive-motivational barriers)}

\subsubsection{Common barriers regardless of the type and time of acquiring the disability}

Almost all people with disabilities who have enrolled at a university or completed their studies face architectural barriers. Persons with disabilities in the process of studying (or graduates) have successfully overcome barriers of an architectural nature.

\subsubsection{Architectural barriers and persons with motor disabilities}

For people with motor disabilities, there are three ways of overcoming architectural barriers. The first is the rational choice of the accessible faculty. Another form of overcoming the barriers is the primary support that disabled people have. The third way is bypassing a standardized way of attending classes and passing exams and using an alternative one (teaching and exams in places accessible to persons with motor disabilities).

\subsubsection{Architectural barriers and people with sensory disabilities}

Unlike people with motor disabilities, persons with sensory disabilities overcome architectural barriers in different ways. One way is learning spatial orientation (with minor support from their parents), which is mastered in secondary school for people with hearing impairments, while another way (due to the lack of spatial orientation caused by attending regular school) is the support of a personal assistant, whose assistance helps the student easily overcome architectural barriers.

\subsubsection{Barriers specific to the type and time of acquiring the disability}

Although people that are attending university or have graduated from it face the same problems regardless of the type of disability, we can also target barriers characteristic of a certain type of disability.

\subsubsection{Unadapted processes of taking exams and persons with motor disabilities}

The sensitivity of professors and assistants is one of the dominant ways in which people with motor disabilities (M. O.; A. C.; D. S.; D. R.) overcome (or continue to overcome) the barrier of inaccessible examination taking. Although the possibility of taking an exam is the right of the student defined by legal regulations, the way in which the exam is adapted to students is not clearly defined but is left to the teaching staff.

\footnotetext{
${ }^{21}$ Essential in terms of self-confidence, determination, and self-evaluation.

${ }^{22}$ The inability to overcome social barriers is generally correlated with motor disabilities, although one positive experience occurs in the research (in which case the architectural barrier is not overcome).
} 


\subsubsection{Unadapted literature and people with sensory disabilities}

A typical obstacle for people with sensory disabilities (visual impairment) can be targeted as unadapted literature. Respondents (I. I. and M. M.) overcame it through adapting the literature themselves and using the help of primary support. The survey shows that respondents who overcome the problems of an institutional nature and graduate from university achieve this in a much more difficult manner than those without (this type of) disability. A significant finding of the research which is important to institutional issues (adapting literature, adapting lectures and tutorials, overcoming communication problems, and adapting exams) is overcome by primary support persons that take on the role of pedagogical assistants.

4.2.2.3. Inability to communicate and persons with complete hearing impairment

The case in which social distance has occurred due to the inability to establish communication with a peer group and the teaching staff is the case of a person with complete hearing impairment (M. O.). Due to the lack of adequate pedagogical assistance as an institutional solution to the problem, social distance is overcome through primary support (mother). In this way, when the primary support person took over the role of a pedagogical assistant, it created a pleasant environment for the integration of a person with hearing impairment in the peer group and the social environment.

\section{CONCLUSION AND RECOMMENDATIONS}

Based on the results, it can be said that the low level of integration and participation of persons with disabilities in the process of tertiary education is a consequence of the existence of real barriers that PwDs encounter not only in the education system but also on a daily basis. This research has confirmed that structural conditions in the form of architectural and institutional barriers directly affect the ability of PwDs to study and lead to social exclusion from tertiary education.

It is evident that in the Republic of Serbia, we cannot talk about the dominance of the social model of approach to disability for the following reasons: 1) the existing barriers are not addressed systematically and by adapting the social environment and institutions to the capabilities of PwDs, and 2) the entire way through tertiary education is dependent on the individual's skills and the availability of primary support.

Therefore, the basic findings of this research can be summarized as follows:

1. The accumulation of more than one barrier prevents people with different types of disabilities to engage in the tertiary-education process;

2. A part of the barriers can be overcome systemically, but, in that case, overcoming them depends on the infrastructure of each faculty individually;

3. Primary support has an extremely important role in overcoming various types of barriers, ${ }^{23}$

\footnotetext{
${ }^{23}$ People in the process of studying or who have graduated from university emphasize that without primary support, they would not be able to compensate the failures at the systemic level (for example, personal and pedagogical assistance).
} 
4. A barrier characteristic exclusively for the group of people with disabilities with complete hearing impairment is the cognitive-motivational barrier (directly disabling this population from participating in tertiary education);

5 . The intensity of the social distance directly correlates with the innate/acquired character of the disability; ${ }^{24}$

6. Social distance and negative experiences with peers / professors are overcome through primary support.

In accordance with the previous findings of the analysis, the recommendations for each type of detected barriers have been formulated. The aim of the proposed measures is the social inclusion and integration of PwDs not only in the educational system but also in the wider social community. The implementation of the proposed measures would result in the equalization of life opportunities for equal educational participation of all citizens, the improvement of the position of PwDs in the labor market, ${ }^{25}$ their social inclusion in all channels of social life, and the possibility of a quality, independent and dignified life.

Recommendations for improving the physical accessibility of the faculty:

The strict application of legislation on the accessibility of the facilities in accordance with the prescribed standards at all faculties;

The adaptation of the streets and the environment in accordance with the prescribed standards;

The problem of unadapted transport should be dealt with in two ways: 1) by introducing regular lines (low-floor buses) to all tertiary-education institutions; 2) by working on training drivers in order to enable them to handle ramps;

Personal assistance services should be regulated at the institutional level in the sense that assistants should receive the status of civil servants $;^{26}$

Increase the number of student dormitory rooms for PwDs adapted to their capabilities (according to the Rulebook on Technical Accessibility Standards);

Adapt canteens to the capabilities of PwDs according to the same policy.

\subsection{Recommendations for resolving institutional barriers:}

1. Continuous work on the availability of information on two levels: 1) university employees must have information about the method of taking exams and quotas for PwDs; and 2) regular updates of faculty websites in order to make the mentioned data available and guide the students to sources of information;

2. Entrance exams should be organized in facilities accessible to PwDs;

3. Apart from disability, the only condition for exercising the right to a scholarship from the Ministry of Education for PwDs should be that they have qualified for the government-funded status of their studies;

4. Designing a manual for the customized assessment of PwDs, whose content should be in line with the equivalently standardized model of assessment for the student population;

\footnotetext{
${ }^{24}$ Social distance is lower in cases of acquiring the disability later (during life).

25 Assuming education is a legitimate social channel for occupying a position in the labor market and for assessing the quality and competence of the workforce.

${ }^{26}$ Instead of the past practice of financing them through projects.
} 
5. Establishment of a special body (secondary school or university student support office) whose goal is to provide services to young secondary school and university students; ${ }^{27}$

6. Professors' books as part of a narrower or wider volume of literature for preparing for exams must exist in PDF format and they should be regularly distributed to students with sensory disabilities via e-mail;

7. The tertiary education institution is obliged to adapt the literature for PwDs (scanning and uploading to a program whose voice software recognizes /PDF, Word, TXT/);

8. The existence of computers that allow work with voice software and make it easier for people with disabilities to use a computer. The recommendations are Microsoft Narrator or the JAWS software;

9. Compulsory teaching staff training for additional skills on the ways of transferring knowledge to people who are users of speech software;

10. The introduction of pedagogical assistants with a good knowledge of sign language into the teaching process. $^{28}$

\subsection{Recommendations for overcoming social barriers:}

1. Stricter control of violence by teachers in a way that open discrimination and mistreatment are punished pedagogically;

2. Socialization of children using inclusive education methods, which makes children sensitive to diversity;

3. Organizing an accredited professional seminar on the topic of "People with Disabilities in Tertiary Education" with the aim of sensitizing teaching and non-teaching staff and combating prejudice and social distance towards PwDs.

\subsection{Recommendations for overcoming cognitive-motivational barriers:}

1. The problem of cognitive-motivational barriers is solved in several ways. The first way is the complete integration of people with hearing impairments into the regular education system with the necessary support of a pedagogical assistant in the teaching process. The second aspect would be to enrich the teaching content in special schools for people with hearing impairments, while the third way of resolving the cognitivemotivational barriers would be a combination of these two proposals.

Acknowledgement: The paper is a part of the research done within the project Tradition, Modernization and National Identity in Serbia and the Balkans in the European Integration Process (179074), financed by the Ministry of Science and Technological Development of the Republic of Serbia and implemented by the Centre for Sociological Research at the Faculty of Philosophy, University of Niš.

\footnotetext{
${ }^{27}$ Support is expressed through support in mastering an effective way of learning, the possibility of directing secondary school students using professional orientation tests, sending regular notifications of opportunities and enrollment conditions for faculties, and other requirements of pupils or students with and without disabilities.

${ }^{28}$ Pedagogical assistants in teaching would be a constant support to people with hearing impairment in the teaching process, helping disabled people in mastering barriers in lectures (retelling the events in their surroundings) and helping them overcome barriers of an institutional nature (adapting literature and reading).
} 


\section{REFERENCES}

Blažeka Kokorić, S. at al. "Satisfaction with Life and Informal and Formal Sources of Support among People with Disabilities". Društvena istraživanja 21, 1, 114 (2012): 19-38.

Dinkić at al. Servisi socijalne zaštite za osobe sa invaliditetom: usklađivanje politike i prakse. Beograd: Centar za samostalni život invalida Srbije, 2008.

Dejong, G. "Independent Living: From Social Movement to Analytic Paradigm". Arch Phys Med Rehabil 60 (1979): 435-446.

Gidens, E. Sociologija. Beograd: Ekonomski fakultet u Beogradu, 2007.

Council of the European Union. Joint Report by the Commission and the Council on Social Inclusion. Brussels, 2004.

Law on the Confirmation of the Convention on the Rights of Persons with Disabilities ("Official Gazette of the Republic of Serbia - International Agreements", 42/2009).

Law on the Prevention of Discrimination of Persons with Disabilities ("Official Gazette of the Republic of Serbia", 33/2006).

Law on Tertiary Education ("Official Gazette of the Republic of Serbia", 76/2005, 100/2007 - authentic interpretation, 97/2008, 44/2010, 93/2012, 89/2013, 99/2014, 45/2015 - authentic interpretation and 68/2015).

Mirić, F. "Kvalitet života osoba sa invaliditetom u Srbiji". Socijalna misao 21, 2 (2014): 47-57.

Petrović, J. "Jezik invalidnosti i dominantni teorijski okviri proučavanja kao indikatori socijalnog položaja osoba sa invaliditetom". Zbornik radova Filozofskog fakulteta u Prištini 36 (2007): 259-270.

Petrović, J. Ogledi o obrazovanju u Srbiji - pogled na skrajnuta pitanja. Kosovska Mitrovica: Filozofski fakultet u Prištini sa privremenim sedištem u Kosovskoj Mitrovici, 2012.

Rawal, N. "Social Inclusion and Exclusion - A Review". Dhaulagiri Journal of Sociology and Anthropology 2 (2008): 161-180.

Rot, N. Socijalna psihologija. Beograd: Zavod za udžbenike i nastavna sredstva, 2003.

Sen, A. Social Exclusion: Concept, Application, and Scrutiny. Social Development Papers 1. Philippines, Manila: Office of Environment and Social Development, Asian Development Bank, 2000

Silver, H. "Social Exclusion and Social Solidarity: Three Paradigms". International Labour Organization 133, 5-6 (1994): 531-578.

Silver, H., and S. M. Miller. "Social Exclusion - The European Approach to Social Disadvantage". Indicators 2, 2 (2003): 1-17.

The Constitution of the Republic of Serbia ("Official Gazette of the Republic of Serbia", 98/2006).

The Convention on the Rights of Persons with Disabilities. Available at: http://www.mhrr.gov.ba/PDF/ Konvencija_bos.pdf (accessed on February 11, 2017).

The Law on the Prohibition of Discrimination ("Official Gazette of the Republic of Serbia", 22/2009).

The Social dimension of Higher Education in Serbia, As-is State Report (as part of the Tempus Equied Project), 2012. Available at: http://www.equied.ni.ac.rs/vesti/107-dostupna-studija-zatecenog- stanja.html

\section{SOCIJALNA ISKLJUČENOST OSOBA SA INVALIDITETOM IZ VISOKOG OBRAZOVANJA - TARGETIRANJE BARIJERA U ZAVISNOSTI OD TIPA INVALIDITETA NA OSNOVU KVALITATIVNOG ISTRAŽIVANJA}

U ovom radu smo se prevashodono bavili malom zastupljenošću osoba sa invaliditetom u sistemu visokog obrazovanja i barijerama sa kojima se one susreću u procesu visokog obrazovanja. Pomenutom problemu je pristupljeno iz perspektive socijalne isključenosti, a jedan od zadataka sprovedenog istraživanja jeste da se stekne uvid u to sa kojom se vrstom barijera susreću osobe sa različitim vidom invaliditeta u zavisnosti od njihovog studentskog statusa (nisu upisali fakultet, odustali od studija, u toku su procesa studiranja, završili studije). Do rezultata se došlo sprovođenjem dubinskih intervjua kojim su obuhvaćene sve pomenute kategorije osoba sa invaliditetom. Sprovedenim istraživanjem se došlo do vrednih rezultata koji ukazuju na postojanje brojnih prepreka sa kojima se osobe sa invaliditetom suočavaju u procesu sticanja visokog obrazovanja. Pokazalo se da su se ispitivane osobe sa invaliditetom suočavale sa arhitektonskim, institucionalnim i socijalnim barijerama u zavisnosti od vrste invaliditeta $i$ socijalnog okruženja.

Ključne reči: socijalna isključenost, obrazovanje, osobe sa invaliditetom, barijere. 